\title{
Enhancement of microbial transglutaminase production from Streptomyces sp.
}

\section{Izzet Turker ${ }^{1}$, Gokhan Domurcuk ${ }^{1}$, Mehmet Tokatli ${ }^{1}$, Hilal Isleroglu' ${ }^{1}$, Banu Koc ${ }^{2}$}

1 - Gaziosmanpasa University, Faculty of Natural Sciences and Engineering, Food

Engineering Department, Tokat, Turkey

2 - Gaziantep University, Fine Arts, Gastronomy and Culinary Arts, Gaziantep, Turkey

\section{Keywords:}

Microbial

Transglutaminase

S. Mobaraensis

Enzyme

Activity

Fermentation

\section{Article history:}

Received 14.01.2016

Received in revised form 29.03.2016

Accepted 30.06.2016

\section{Corresponding} author:

Hilal Isleroglu

E-mail:

hilal.isleroglu@

gop.edu.tr

\section{Abstract}

Introduction. Enhancement of microbial transglutaminase (MTGase) production was investigated in terms of creating a model for future studies about the usage of microbial transglutaminase which might become popular in the next years.

Materials and methods. In order to determine the highest enzyme activity, the effects of temperature, $\mathrm{pH}$, medium and type of strains have been investigated. Five different strains were selected to produce MTGase: Streptomyces mobaraensis (NRRL B-3729), S. ladakanum (NRRL ISP-5587), S. lividans (NRRL B-12275), S. sioyaensis (NRRL B-5408) and $S$. platensis (NRRL B-5486). The fermentation process carried out using two fermentation media based on glucose-starch and soy with different $\mathrm{pH}$ and temperatures $(6.0,7.0,8.0 \mathrm{pH}$ and 20, 30, $40{ }^{\circ} \mathrm{C}$ ). MTGase activity had been determined for 28 days by hydroxamate-based colorimetric method.

Results and discussions. S. mobaraensis, S. ladakanum and $S$. lividans showed greater growth rates than $S$. sioyaensis and $S$. platensis. In that case, $S$. mobaraensis, S. ladakanum and S. lividans were selected for the enzyme production. At pH 6.0, the highest enzyme activity $(0.036 \mathrm{U} / \mathrm{ml})$ was achieved by $S$. mobaraensis in glucose-starch medium at $30{ }^{\circ} \mathrm{C}$ for 14 days and the enzyme activity decreased dramatically after $14^{\text {th }}$ day of fermentation for all strains. At $\mathrm{pH} 7.0$, the highest enzyme activity was seen on $28^{\text {th }}$ day of incubation for $S$. mobaraensis at $30{ }^{\circ} \mathrm{C}$. At $\mathrm{pH}$ 8.0, MTGase could not be produced in any of the culture media, or at any temperatures and $\mathrm{pH}$ value. For initial $\mathrm{pH} 6.0$ value, the increasing rate of MTGase activity in glucose-starch based medium was higher than in soy based medium at all different temperatures $\left(20,30\right.$ and $\left.40{ }^{\circ} \mathrm{C}\right) . S$. ladakanum and $S$. lividans could not produce MTGase for none of the conditions.

Conclusions. S. mobaraensis yielded the highest enzyme activity when compared with other strains. Glucose-starch based medium was the most suitable medium for MTGase production. $\mathrm{pH}$ and temperature changes affected the enzyme activity and $\mathrm{pH} 6.0$ and $30^{\circ} \mathrm{C}$ were the best conditions for the production of MTGase. 


\section{Introduction}

Transglutaminase (TGase; protein-glutamine-glutamyl-transferase, EC 2.3.2.13) is an enzyme capable of catalyzing acyl transfer reactions by introducing covalent cross-links between proteins as well as peptides and various primary amines [1]. When the amine substrates are absent in the medium, TGase can catalyze the hydrolysis of the $\gamma$ carboxyamide group of the glutaminyl residue, resulting in deamination. When the $\varepsilon$-amino group of a peptide-bound lysyl residue is the substrate, peptide chains are covalently connected through by TGase $\varepsilon$-( $\gamma$-glutamyl) lysine (G-L) bonds [2]. Transglutaminase has been found in animals, plants, and microorganisms [3]. Recently, TGase has captured peoples' interest due to its potential application for various food products $[4,5]$.

There are three ways to produce TGase. The first approach is extraction and purification of the enzyme from body fluids and tissues of animals. Factor XIII, extracted from the blood of cattle, was the first commercially produced TGase in Europe [6]. However, the blood enzyme needed thrombin to be active and when used for food products, red pigmentation affected the appearance. The second approach is producing the enzyme by using genetic manipulation. In this purpose, many researchers experimented to produce TGase within the host microorganisms as E. coli, Bacillus and Aspergillus [7-9]. Although being a low-costed method, because of consumers disclaim, second approach could not be an applicable method to obtain commercial TGase [2]. The third approach is finding an appropriate microorganism and produce TGase by using fermentation technology. Several reviews on the application of microbial transglutaminase (MTGase) in food and other areas are already available in the literature $[2,3,5,10]$.

The production of MTGase by Streptoverticillium mobaraense was first reported by Ando et al. [11]. It was reported that MTGase can catalyze acyl transfer reactions by introducing covalent cross-links between proteins like blood and tissue TGase. Furthermore, MTgase do not require $\mathrm{Ca}^{+2}$ or thrombin for activation. For commercial production, MTGase can be easily isolated from the culture broth. MTGase from Streptoverticillium sp. used for several food applications such as producing polymers of casein and soybean proteins and gelatinizing sodium caseinate and skim milk gels [12, 13$]$.

Streptomyces species are able to produce MTgase in different structures and these species are commonly used for the industrial production of MTGase. Accordingly, researchers are focused on enhancement of the production of MTGase by using Streptomyces species in terms of factors affecting enzyme activity such as substrate optimization, metabolic optimization, and extrinsic factors $(\mathrm{pH}$, dissolved oxygen and temperature etc.). Altering the parameters about fermentation may cause to increase the enzyme activity and hereby increasing the enzyme activity may lower the costs of the production [14]. Because of consideration in the usage of MTGase will become popular, in this study enhancement of MTGase production was investigated in terms of creating a model for future studies. For determination of the highest enzyme activity, the effects of temperature, $\mathrm{pH}$, medium and type of strains have been investigated.

\section{Materials and methods}

Materials. All the chemicals used were of analytical grade and mainly purchased either from Sigma Chemical Co., Ltd. or Merck Millipore Corporation. Z-Gln-Gly ( $\gamma$-glutamyl donor substrate), was purchased from Sigma Chemical Co., Ltd. Streptomyces mobaraensis NRRL B-3729, S. ladakanum NRRL ISP-5587, S. lividans NRRL B-12275, S. sioyaensis NRRL B-5408 and $S$. platensis NRRL B-5486 were obtained from USDA Agricultural 
Research Service. Perkin-Elmer Lambda EZ 201 spectrophotometer was used for the enzyme assays.

Culture conditions and MTGase Production. All strains were pre-cultured on a medium composed of: glucose $(4.0 \mathrm{~g} / \mathrm{L})$, yeast extract $(4.0 \mathrm{~g} / \mathrm{L})$ and malt extract $(10.0 \mathrm{~g} / \mathrm{L})$ at $\mathrm{pH} 7.2,30^{\circ} \mathrm{C}$. After 6 days of incubation, S. mobaraensis, S. ladakanum and S. lividans showed greater growth rates than $S$. sioyaensis and $S$. platensis. In that case, $S$. mobaraensis, $S$. ladakanum and $S$. lividans were selected for the enzyme production. Two different media were prepared for MTGase production. The first medium based on glucosestarch composed of: glucose $(15 \mathrm{~g} / \mathrm{L})$, starch $(15 \mathrm{~g} / \mathrm{L})$, peptone $(15 \mathrm{~g} / \mathrm{L})$, yeast extract (4 $\mathrm{g} / \mathrm{L}), \mathrm{MgSO}_{4}(2 \mathrm{~g} / \mathrm{L}), \mathrm{KHPO}_{4}(2 \mathrm{~g} / \mathrm{L})$ and $\mathrm{KH}_{2} \mathrm{PO}_{4}(2 \mathrm{~g} / \mathrm{L})$ [15]. The second medium based on soy composed of: soy $(20 \mathrm{~g} / \mathrm{L})$, glycerol $(10 \mathrm{~g} / \mathrm{L})$, peptone $(15 \mathrm{~g} / \mathrm{L})$, starch $(5 \mathrm{~g} / \mathrm{L})$, glucose $(5 \mathrm{~g} / \mathrm{L})$, yeast extract $(5 \mathrm{~g} / \mathrm{L}), \mathrm{CaCO}_{3}(5 \mathrm{~g} / \mathrm{L}), \mathrm{MgSO}_{4}(2 \mathrm{~g} / \mathrm{L}), \mathrm{KHPO}_{4}(2 \mathrm{~g} / \mathrm{L})$ and $\mathrm{KH}_{2} \mathrm{PO}_{4}(2 \mathrm{~g} / \mathrm{L})$ [1]. To determine the effect of different temperatures and $\mathrm{pH}$ values on MTGase production, S. mobaraensis, S. ladakanum and S. lividans were inoculated in both glucose-starch based medium and soy based medium, initial $\mathrm{pH}$ values were adjusted to 6.0, 7.0 and 8.0. Samples had been incubated for 28 days at 20,30 and $40{ }^{\circ} \mathrm{C}$ were analyzed to determine MTGase activity.

Determination of MTGase activity. MTGase enzyme activity was determined by Hydroxamate formation with the specific substrate of Z-Gln-Gly. The reaction mixture contained $100 \mu \mathrm{l}$ enzyme solution and $325 \mu \mathrm{l}$ substrate solution $(200 \mu \mathrm{l}$ of $200 \mathrm{mM}$ Tris$\mathrm{HCl}, 25 \mu \mathrm{l}$ of $12.5 \mathrm{mM}$ reduced glutathione, $25 \mu \mathrm{l}$ of $125 \mathrm{mM}$ hydroxylamine and $75 \mu \mathrm{l}$ of $37.5 \mathrm{mM}$ Z-Gln-Gly). The solution was incubated at $37{ }^{\circ} \mathrm{C}$ for 24 hours and then it was ended by adding $425 \mu \mathrm{l}$ of stop reagent (consisting of $15 \%$ TCA and $5 \% \mathrm{FeCl}_{3}$ ). After centrifugation at $11000 \mathrm{rpm}$ for 5 minutes, the absorbance of the supernatant was measured at $525 \mathrm{~nm}$. Assay was also carried out using the enzyme blanks. One unit of MTGase activity was described as the amount of enzyme which caused the formation of $1.0 \mu$ mole of hydroxamate per minute by catalyzing the reaction between Z-Gln-Gly and hydroxylamine at $\mathrm{pH} 6.0$ and $37^{\circ} \mathrm{C}$ by using L-glutamic acid $\gamma$-monohydroxamate as a standard $[16,17]$.

\section{Results and discussion}

All five lyophilized strains obtained from USDA were pre-cultured on a medium composed of glucose, yeast extract and malt extract. S. mobaraensis, S. lividans and $S$. ladakanum were selected for the MTGase production of enzyme. These strains were reproduced once in two days for the first week, and this procedure was repeated every couple of weeks. For preparation of the stock culture, cultured media were centrifuged and bacterial pellet was obtained. Following the centrifugation, sterilized pre-culturing medium containing 30\% glycerol $(\mathrm{v} / \mathrm{v})$ was added on the bacterial pellet and stock cultures were stored inside cryotubes at $-65^{\circ} \mathrm{C}$. For the enzyme production, fresh cultures which obtained from pre-culturing medium were inoculated in (1\%) glucose-starch and soy based media. After 28 days of incubation, S. mobaraensis yielded the highest enzyme activity. However, S. ladakanum and $S$. lividans could not produce MTGase for none of the culture mediums, temperatures and $\mathrm{pH}$ value. Some researchers attempted to produce MTGase by genetic modification methods from $S$. ladakanum and $S$. lividans strains which produce MTGase very slightly $[18,19]$. On the other hand, according to the Tellez-Luis et al. [20], $S$. ladakanum is able to produce MTGase $(0.725 \mathrm{U} / \mathrm{ml})$ in the presence of casein and glycerol in the broth medium. In the same way, Ho et al. [21] produced MTGase $(2.40 \mathrm{U} / \mathrm{ml})$ by using agitating fermenter from $S$. ladakanum. 

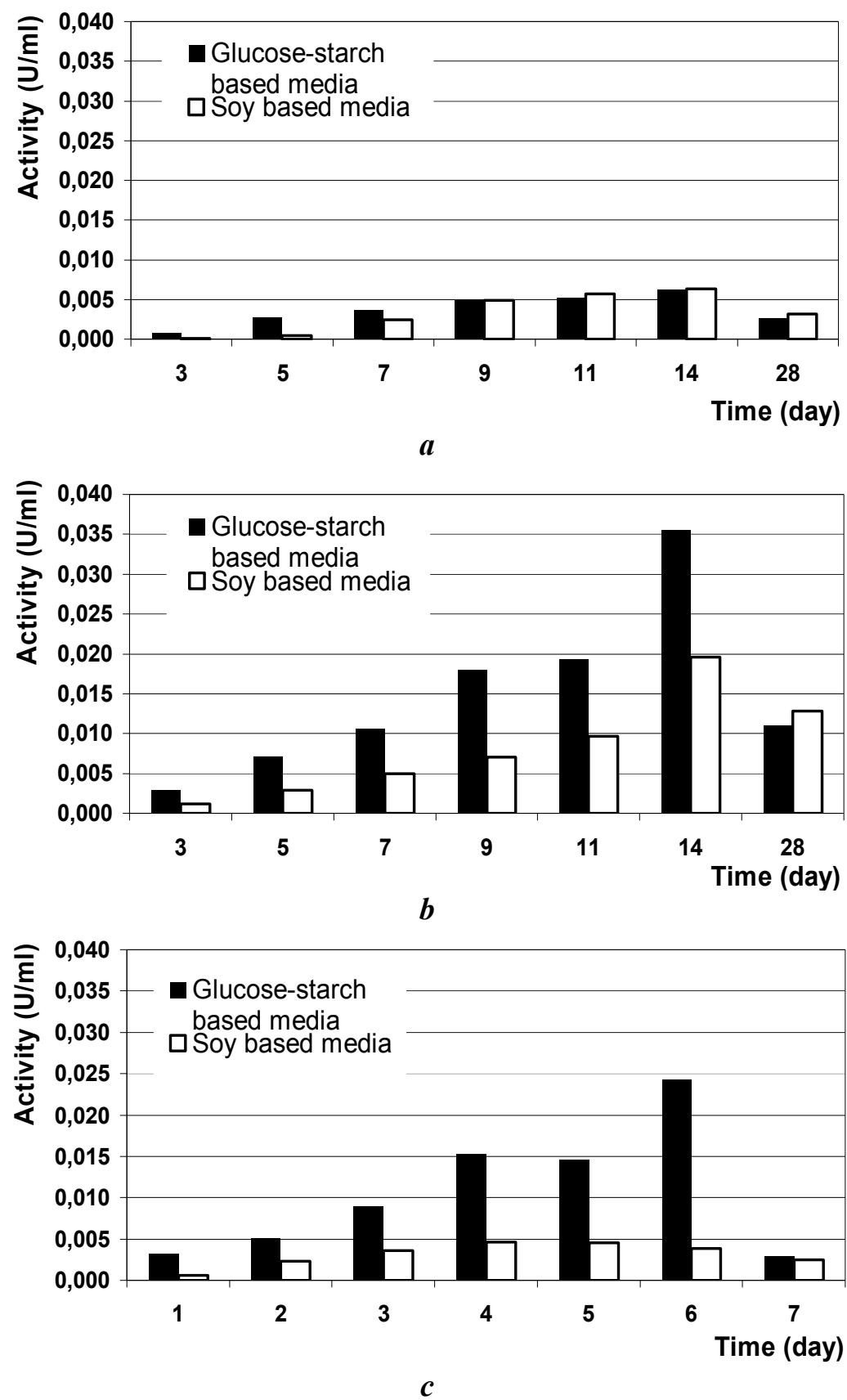

Figure 1. Effect of the different incubation temperatures on the enzyme activity of $S$. mobaraensis for glucose-starch based medium (dark grey) and soy based medium (light grey) at initial pH of 6.0:

$a-20^{\circ} \mathrm{C}, b-30^{\circ} \mathrm{C}, c-40^{\circ} \mathrm{C}$. 

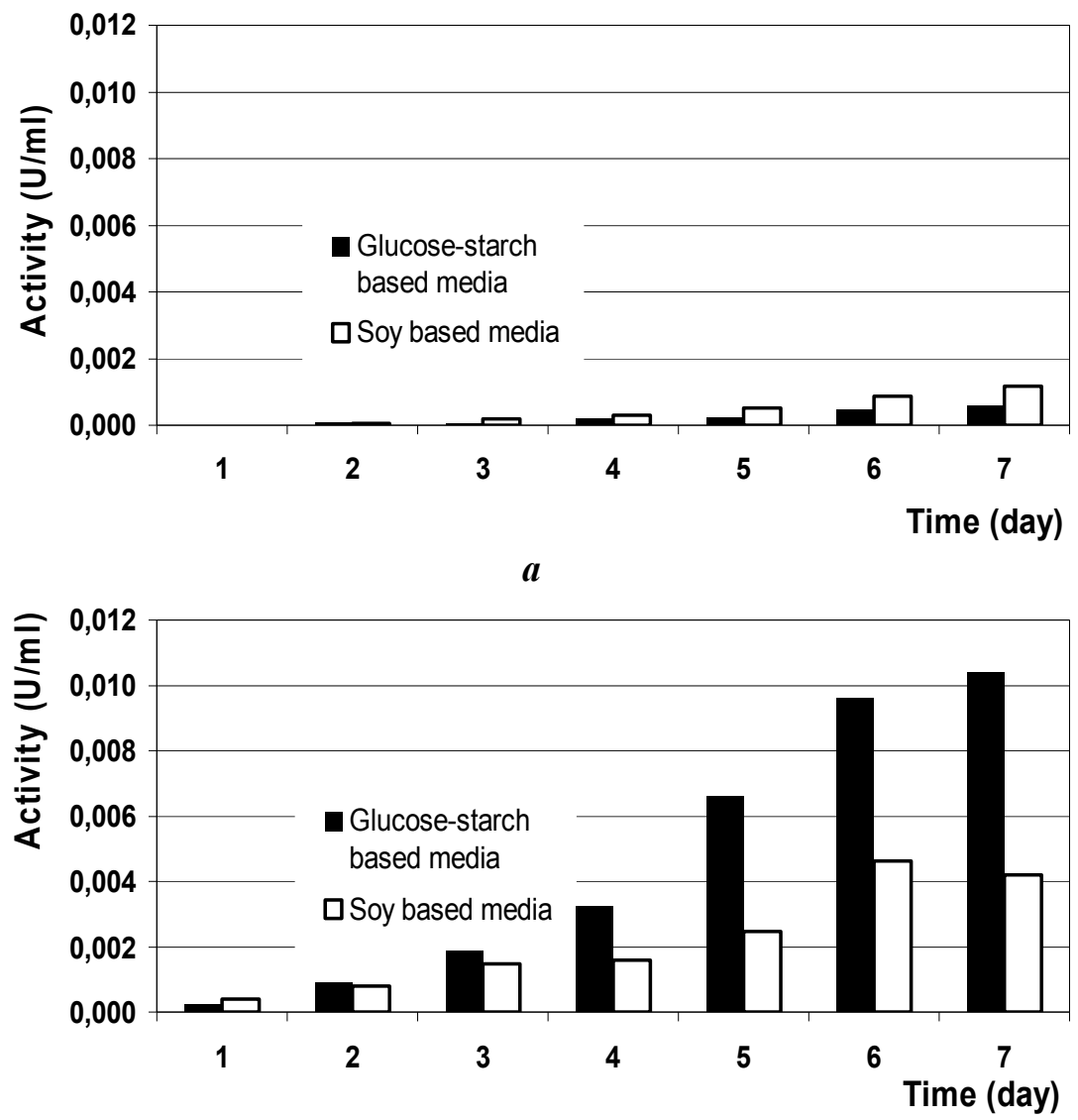

$b$

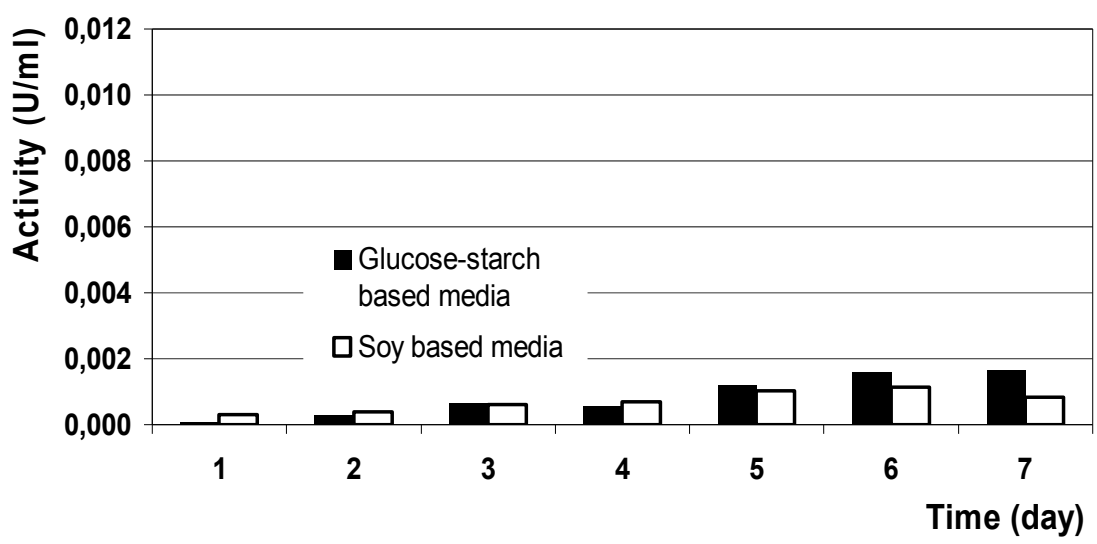

$c$

Figure 2. Effect of the different incubation temperatures on the enzyme activity of $S$. mobaraensis for glucose-starch based medium (dark grey) and soy based medium (light grey) at initial pH of 7.0:

$$
a-20{ }^{\circ} \mathrm{C}, b-30{ }^{\circ} \mathrm{C}, c-40{ }^{\circ} \mathrm{C} \text {. }
$$


Figure 1 shows that the highest activity for all experimental conditions was found at 30 ${ }^{\circ} \mathrm{C}, 14^{\text {th }}$ day of incubation. The results for glucose-starch based medium and soy based medium were $0.036 \mathrm{U} / \mathrm{ml}$ and $0.020 \mathrm{U} / \mathrm{ml}$, respectively. In the same way, Zheng et al. [22] carried out the effects of the temperature to the fermentation of Streptovericillium mobaraense and reached the highest enzyme activity at $30^{\circ} \mathrm{C}(2.90 \mathrm{U} / \mathrm{ml}$ at $\mathrm{pH} 6.5)$. The glucose-starch based medium had the lowest enzyme activity at $20^{\circ} \mathrm{C}$. Likewise, soy based medium showed the lowest enzyme activity at 20 and $40{ }^{\circ} \mathrm{C}$. The highest activity at $20{ }^{\circ} \mathrm{C}$ was reached on the $14^{\text {th }}$ day of incubation for both media $(\sim 0.006 \mathrm{U} / \mathrm{ml})$. Temperature might considerably affect the specific cell growth rate of microorganisms. Therefore, the amount of MTGase activity can be related with specific cell growth rate of $S$. mobaraensis [22]. Glucose-starch based medium had an acceptable enzyme activity $(0.024 \mathrm{U} / \mathrm{ml})$ at 40 ${ }^{\circ} \mathrm{C}$ as well. However, the enzyme activity decreased dramatically after $14^{\text {th }}$ day of incubation for all samples at 20,30 and $40{ }^{\circ} \mathrm{C}$.

For initial $\mathrm{pH}$ 6.0, the increasing rate of MTGase activity in glucose-starch based medium was higher than in soy based medium at all different temperatures (20, 30 and 40 $\left.{ }^{\circ} \mathrm{C}\right)$. Tellez-Luis et al. [20] reported that using of glycerol and casein in the medium had positive impact on producing MTGase from S. ladakanum. On the other hand, in the medium, cross-linking of peptides may occur by MTGase. For our soy based medium, free amino acids may be probably limited the MTGase production.

As shown in Figure 2, at initial $\mathrm{pH}$ 7.0, the highest enzyme activities for both glucosestarch based medium and soy based medium at $30{ }^{\circ} \mathrm{C}$ were $0.010 \mathrm{U} / \mathrm{ml}, 0.004 \mathrm{U} / \mathrm{ml}$, respectively similar to initial $\mathrm{pH}$ 6.0. We concluded that glucose-starch based medium had high amount of enzyme activity when compared with soy based medium likewise at $\mathrm{pH}$ 6.0. For the temperatures 20 and $40{ }^{\circ} \mathrm{C}$, there were slight changes on the MTGase activity. At $\mathrm{pH} 7.0$, the highest enzyme activity was seen on $28^{\text {th }}$ day of incubation unlike $\mathrm{pH}$ 6.0. In our study, because of having low enzyme activity at $\mathrm{pH} 8.0$ for both media, the data was not shown in this paper. Meiying et al. [23] stated that $S$. mobaraense cannot grow normally in acidic or slightly alkaline medium. Hydrogen bonds may not be formed; consequently, protein molecule bond formation cannot be established. They suggested that to maximize the specific cell growth rate the $\mathrm{pH}$ value should be controlled at 7.0. However, we reached the highest enzyme activity value at initial pH 6.0.

\section{Conclusions}

S. mobaraensis showed the highest MTGase activity when compared with S. lividans and S. ladakanum. MTGase activity of $S$. mobaraensis was crucially affected by medium type, different temperatures and $\mathrm{pH}$ values. The effect of temperature $\left(20,30\right.$ and $\left.40{ }^{\circ} \mathrm{C}\right)$, $\mathrm{pH}(6.0,7.0$ and 8.0) and two different media (glucose-starch based and soy based medium) on the enzyme activity was investigated and it was reached that the highest enzyme activity $(0.036 \mathrm{U} / \mathrm{ml})$ at $30^{\circ} \mathrm{C}, \mathrm{pH} 6.0$ and in glucose-starch based medium. To maintain maximum MTGase production, in addition to the temperature and $\mathrm{pH}$, other parameters such as dissolved oxygen and agitation may also be changed. Instead of ready to use medium, molasses or waste products can be used as carbon source for the production of MTGase.

Acknowledgements. This research was supported by the Scientific and Technical Research Council of Turkey (Project No. $115 \mathrm{O} 216$ ). 


\section{References}

1. Cui L., Du G., Zhang D., Liu H., Chen J. (2007), Purification and characterization of transglutaminase from a newly isolated Streptomyces hygroscopicus, Food Chem, 105, pp. 612-618.

2. Yokoyama, K., Nio N., Kikuchi Y. (2004), Properties and application of microbial transglutaminase, Appl. Microbiol. Biotechnol, 64(4), pp. 447-454.

3. Zhu Y., Tramper J. (2008), Novel applications for microbial transglutaminase beyond food processing, Trends Biotechnol, 26, pp. 559-565.

4. Motoki M., Seguro K. (1994), Trends in Japanese soy protein research, Inform, 5, pp. 308-313

5. Zhu Y., Rinzema A., Tramper J., Bol J. (1995), Microbial transglutaminase - a review on its production and application in food processing, Appl. Microbiol. Biotechnol, 44, pp. 277-82.

6. Wilson S.A. (1992), Modifying meat proteins via enzymatic crosslinking, Proceedings of the 27th Meat Industry Research Conference, Hamilton, Meal Industry Research Institutes of New Zealand, Mirinz, pp. 247-277

7. Bishop P.D., Teller D.C., Smith R.A., Lasser G.W., Gilbert T., Seale R.L. (1990), Expression, purification, and characterization of human factor XIII in Saccharomyces cerevisiae., Biochemistry, 29, pp. 1861-1869.

8. Washizu K., Ando K., Koikeda S., Hirose S., Matsuura A., Akagi H., Motoki M., Takeuchi K. (1994), Molecular cloning of the gene for microbial transglutaminase from Streptoverticillium and its expression in Streptomyces lividans, Biosci Biotechnol Biochem., 58, pp. 82-87.

9. Yokoyama K.I., Nakamura N., Seguro K., Kubota K. (2000), Overproduction of microbial transglutaminase in Escherichia coli, in vitro refolding, and characterization of the refolded form, Biosci. Biotechnol. Biochem., 64, pp. 1263-1270.

10. Motoki M., Seguro K. (1998), Transglutaminase and its use for food processing, Trends Food Sci. Technol., 9, pp. 204-210.

11. Ando H., Adachi M., Umeda K., Matsuura A., Nonaka M., Uchio R., Tanaka H., Motoki M. (1989), Purification and characterization of a novel transglutaminase derived from microorganisms, Agric. Biol. Chem., 53, pp. 2613-2617

12. Nonaka, M., Tanaka H., Okiyama A., Motoki M., Ando H., Umeda K., Matsukuwa A. (1989), Polymerization of several proteins by $\mathrm{Ca}^{2+}$-independent transglutaminase derived from microorganisms, Agric. Biol. Chem., 53, pp. 2619-2623.

13. Nonaka M., Sakamoto H., Toiguchi S., Kawajiri H., Soeda T., Motoki M. (1992), Sodium caseinate and skim milk gels formed by incubation with microbial transglutaminase, J. Food Sci., 57, pp. 1214-1218.

14. Zhang D., Zhu Y., Chen J. (2009), Microbial transglutaminase production: understanding the mechanism, Biotechnol. Genet. Eng. Rev., 26, pp. 205-222.

15. Macedo J. A., Sette L.D., Sato H.H. (2007), Optimization of medium composition for transglutaminase production by a Brazilian soil Streptomyces sp., Electr. J. Biotechnol., 10, pp. 618-626

16. Bourneow C., Benjakul S., Sumpavapol P., Hikıttıkun A. (2012), Isolation and cultivation of transglutaminase-producing bacteria from seafood processing factories, Innov Rom Food Biotechnol., 10, pp. 28-39.

17. Estevinho B.N., Damas A.M., Martins P., Rocha F. (2014), Microencapsulation of $\beta$ galactosidase with different biopolymers by a spray-drying process, Food Res. Int., 64, pp. 134-140. 
18. Lin Y.S., Chao M.L., Liu C.H., Chu W.S. (2004), Cloning and expression of the transglutaminase gene from Streptoverticillium ladakanum in Streptomyces lividans, Process Biochem., 39, pp. 591-598.

19. Kieliszek M., Misiewicz A. (2014), Microbial transglutaminase and its application in the food industry. A review, Folia Microbiol., 59, pp. 241-250.

20. Tellez-Luis S.J., Ramírez J.A., Vázquez M. (2004), Application in restructured fish products of transglutaminase obtained by Streptoverticillum ladakanaum in media made from hydrolysates of sorghum straw, J. Food Sci., 69, pp. 1-5.

21. Ho M.L., Leu S.Z. , Hsieh J.F., Jiang S.T. (2000), Technical approach to simplify the purification method and characterization of microbial transglutaminase produced from Streptoverticillium ladakanum, J. Food Sci., 65, pp. 76-80.

22. Zheng M.Y., Du G.C., Chen J. (2002), pH control strategy of batch microbial transglutaminase production with Streptoverticillium mobaraense, Enzyme Microb. Technol., 31, pp. 477-481.

23. Meiying Z., Guocheng D., Jian C. (2002), pH control strategy of batch microbial transglutaminase production with Streptoverticillium mobaraense, Enzyme Microb. Technol., 31, pp. 477-481. 